\title{
DETERGENT-LIKE ACTION OF TETRAPHENYLBORATE ON PHOSPHOLIPID LABELLING IN GUINEA PIG CORTEX SUBFRACTIONS ${ }^{1}$
}

\author{
J. SCHACHT and B. W. AgranofF \\ Kresge Hearing Research Institute, Neuroscience Laboratory and Department of Biological Chemistry, \\ University of Michigan, Ann Arbor, MI 48104, U.S.A.
}

(Received 15 August 1973. Accepted 15 October 1973)

\begin{abstract}
The addition of $2 \times 10^{-4} \mathrm{M}$ sodium tetraphenylborate to particulate preparations of guinea pig cerebral cortex increases labelling of phosphatidic acid from $\gamma-\left[{ }^{32} \mathrm{P}\right]$-ATP two- to four-fold. The effect was observed in all subcellular fractions studied (nuclear, synaptosomal, mitochondrial and microsomal) and is not blocked by the addition of atropine. Changes in phospholipid labelling similar to those induced by tetraphenylborate can be demonstrated with sodium dodecyl sulphate or sodium desoxycholate. It is suggested that tetraphenylborate stimulates lipid labelling by a detergent-like activation of diglyceride kinase.
\end{abstract}

TETRAPHENYLBORATE, first synthesized by WitTIG $e t$ al. (1949) and employed for the quantitative determination of potassium has received widespread attention largely because of a variety of actions, which in part, can be linked to its potassium-chelating capacity. TPB has been reported to dissociate cells (RAPPAPORT \& HowzE, 1966a), to swell mitochondria (HARRIs \& LEONE, 1966), uncouple oxidative phosphorylation (UTSUMI \& PACKER, 1967), prevent the light-induced uptake of monovalent cations by ch loroplasts (HOR TON \& PACKER, 1967), inhibit ATPases and a number of other enzymes (STANBURY \& WiCkEN, 1969) and to inactivate $\mathrm{AChE}$ of erythrocyte membranes (HERZ et al., 1971). The interest of our laboratories in this compound stemmed from reports that TPB duplicates some pharmacological actions of $\mathrm{ACh}$ at the neuromuscular junction (SEIFTER et al., 1968) and the previous finding that it stimulates phospholipid labelling in particulate fractions of goldfish brain in vitro (HOLLANDER et al., 1969,1970 ) in a way that apparently resembled the stimulation of phospholipid labelling by ACh. Extending our studies on phospholipid labelling in guinea pig nerve endings in response to cholinergic agents (SCHACHT \& AGRANOFF, 1972 $a ; 1973$ ), we investigated further the mode of action of TPB on phospholipid metabolism.

\footnotetext{
'This work was supported by NIH grant NS 03101.

Abbreviations used: $\mathrm{PhA}$, phosphatidic acid (1,2-diacylsn-glycero-3-phosphate); PhIP, PhIP 2 , phosphatidylinositol phosphate, -diphosphate; TPB, sodium tetraphenylborate; DOC, desoxycholate; SDS, sodium dodecyl sulphate.
}

NEURO. 22/4-A

\section{MATERIALS AND METHODS}

\section{Preparation of fractions}

Cerebral cortex from albino, male guinea pigs weighing approx. $300 \mathrm{~g}$ (Camm Research, Wayne, N.J.) was homogenized and subfractionated essentially as described previously (SCHACHT \& AGRANOFF, 1972a). A 10 per cent homogenate in $0.32 \mathrm{M}$ sucrose was centrifuged for $10 \mathrm{~min}$ at $1000 \mathrm{~g}$. The pellet was washed and centrifuged again to yield the nuclear fraction. The combined supernatant fractions were centrifuged for $20 \mathrm{~min}$ at $13,000 \mathrm{~g}$ to yield a crude nerve ending-mitochondrial pellet and a supernatant fraction containing cytosol and microsomes. The nerve ending-mitochondrial pellet was suspended in $30 \mathrm{ml}$ of $0.32 \mathrm{M}$ sucrose, and was layered over three tubes of a discontinuous gradient consisting of $10 \mathrm{ml}$ each of 0.8 and $1.2 \mathrm{M}$ sucrose, then centrifuged in an SW25 rotor for $120 \mathrm{~min}$ at $62,000 \mathrm{~g}$. Fractions collected have been characterized previously (SCHACHT \& AGRANOFF, 1972a): a myelin-rich fraction over $0.8 \mathrm{M}$ sucrose, a nerve endingrich fraction over $1.2 \mathrm{M}$ sucrose and a pellet, containing mitochondria. These fractions as well as the $13,000 \mathrm{~g}$ supernatant fraction were pelleted by centrifuging for $30 \mathrm{~min}$ at $100,000 \mathrm{~g}$. Each pellet was suspended in $0.32 \mathrm{M}$ sucrose. The 'particulate fraction' was prepared by centrifuging a $1000 \mathrm{~g}$ supernatant for $60 \mathrm{~min}$ at $100,000 \mathrm{~g}$, and suspending the resulting pellet in $0.32 \mathrm{M}$ sucrose. All fractions were frozen in a dry-ice-acetone bath and thawed three times.

Incubations were performed at $37^{\circ} \mathrm{C}$ in air with shaking in the following incubation medium (final concentrations): $80 \mathrm{~mm}$ Tris- $\mathrm{HCl}, \mathrm{pH} 7.2 ; 8 \mathrm{~mm} \mathrm{MgSO}_{4} ; 1 \mathrm{~mm}$ ATP and $1 \mathrm{mg}$ protein in a final vol. $0.5 \mathrm{ml}$. Incubations were terminated and lipids extracted with acidified chloroform- 
TABLE 1. LABELLING OF PHOSPHOLIPIDS IN SUBCELLULAR FRACTIONS

\begin{tabular}{|c|c|c|c|c|c|c|c|}
\hline \multirow[b]{2}{*}{ Fraction } & \multirow{2}{*}{$\begin{array}{c}\text { Total protein } \\
\text { (mg) }\end{array}$} & \multicolumn{2}{|c|}{$\mathrm{PhA}$} & \multicolumn{2}{|c|}{ PhIP } & \multicolumn{2}{|c|}{$\mathrm{PhIP}_{2}$} \\
\hline & & control & $+\mathrm{TPB}$ & control & $+\mathrm{TPB}$ & control & $+\mathrm{TPB}$ \\
\hline & & \multicolumn{6}{|c|}{ d.p.m. ${ }^{32} \mathrm{P}$ in lipid } \\
\hline Nuclear & 91 & 2745 & 5368 & 4470 & 5513 & 1243 & 1206 \\
\hline Mitochondria & 47 & 1794 & 4495 & 1834 & 2195 & 278 & 330 \\
\hline Nerve endings & 61 & 3115 & 5744 & 5012 & 4919 & 562 & 686 \\
\hline Myelin & 14 & 1578 & 2594 & 3417 & 2165 & 5190 & 4564 \\
\hline Microsomes & 72 & 1426 & 2566 & 2698 & 2732 & 304 & 343 \\
\hline
\end{tabular}

Fractions were prepared from two cortices. The fractions ( $1 \mathrm{mg}$ protein) were incubated for 5 min with $8 \mu \mathrm{Ci}\left[{ }^{32} \mathrm{P}\right] \mathrm{ATP}$ as described in 'Methods'.

methanol (HAJRA et al., 1968), separated by TLC (Hollander et al., 1970), located by radioautography, scraped and counted by liquid scintillation spectrometry.

Protein was measured spectrophotometrically (LOWRY et al., 1951). $\gamma-\left[{ }^{32} \mathrm{P}\right] \mathrm{ATP}$ was prepared enzymatically (GLYNN \& CHAPPEL, 1964). Sodium TPB was purchased from Sigma (St. Louis, Mo.), SDS from Fisher Scientific (Fairlawn, N.J.) and sodium DOC from Mann Research (New York). Data presented are generally averages of at least duplicate incubations with variability less than 10 per cent.

\section{RESULTS}

\section{Labelling of subcellular fractions}

Fractions obtained by differential and density gradient fractionation were incubated in the presence and absence of $10^{-4} \mathrm{M}$ TPB (Table 1). There was an approximately two-fold variability in the basal unstimulated labelling of $\mathrm{PhA} / \mathrm{mg}$ of protein, with the nerve ending fraction always showing the highest activity of incorporation. The labelling of PhIP and $\mathrm{PhIP}_{2}$, the only other significantly labelled lipids, showed greater variability among the subcellular fractions, but was highest in the myelin-rich fraction. The degree of stimulation of PhA labelling by TPB was similar in all fractions, about two to three-fold, and was variable for PhIP and $\mathrm{PhIP}_{2}$.

\section{Conditions of labelling}

The stimulation of PhA labelling was largely independent of changes in the incubation conditions. Basal labelling was highest around $\mathrm{pH} 7$; TPB stimulation showed a broad optimum range $(6 \cdot 1-7 \cdot 6)$. Omission of magnesium from the medium results in reduced lipid labelling, but the percentage TPB stimulation was unaffected by omission or addition of $\mathrm{Mg}^{2+}$ up to $25 \mathrm{~mm}$. Similarly, presence of $\mathrm{Na}^{+}$and $\mathrm{Ca}^{2+}$ (up to $20 \mathrm{mM}$ ) did not alter the TPB effect. $\mathrm{K}^{+}$, as expected from its precipitation with TPB, could completely abolish the action of TPB. $50 \mathrm{~mm} \mathrm{NaF}$, added to inhibit ATPases, increased basal labelling of PhA two-fold but TPB stimulated labelling also to a similar extent.

\section{$T P B$ dose response}

Stimulated labelling of PhA shows a sharp optimum around $10^{-4} \mathrm{M}$ TPB (Fig. 1). Further studies identified a maximal stimulation at $2 \times 10^{-4} \mathrm{M}$ when the protein present was $1 \mathrm{mg}(2 \mathrm{mg} / \mathrm{ml})$. Increased labelling of PhIP and PhIP 2 is less pronounced than in PhA but
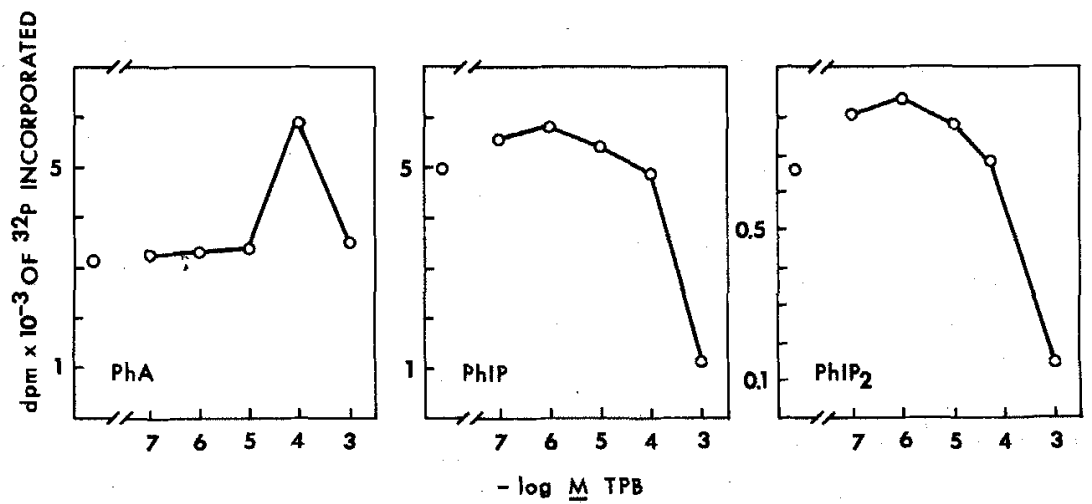

FIG. 1. The particulate fraction of guinea pig cerebral cortex (1 mg protein) was incubated for $5 \mathrm{~min}$ with $7 \mu \mathrm{Ci}\left[{ }^{32} \mathrm{P}\right] \mathrm{ATP}$ as described in 'Methods'. 
TABle 2. INCUBATION OF TISSUE WITH TPB PRIOR TO. LABELLING PULSE

\begin{tabular}{lccc}
\hline $\begin{array}{c}\text { Time of TPB } \\
\text { addition }\end{array}$ & PhA & PhIP & PhIP $_{2}$ \\
\hline \multicolumn{1}{c}{ min } & \multicolumn{2}{c}{ d.p.m. ${ }^{32}$ P incorporated } \\
None added & 942 & 2610 & 267 \\
$\mathrm{~T}_{0}$ & 3406 & 3090 & 159 \\
$-\mathrm{T}_{10}$ & 3668 & 2871 & 131 \\
$-\mathrm{T}_{20}$ & 3669 & 2477 & 134 \\
$-\mathrm{T}_{30}$ & 3202 & 1573 & 105 \\
\hline
\end{tabular}

The particulate fraction ( $1 \mathrm{mg}$ protein) was pre-incubated for $30 \mathrm{~min}$ with $2 \times 10^{-4} \mathrm{M}$ TPB added at times indicated. $\mathrm{T}_{-30}$ indicates TPB was present for entire preincubation period. At $\mathrm{T}_{0}$, ATP $(2 \mu \mathrm{Ci}, 1 \mathrm{mM})$ was added and incubation continued for $5 \mathrm{~min}$. Details as in 'Methods'.

clearly evident here and in comparable experiments (Tables 2, 4 and 5). Beyond the optimum concentration the lipid labelling is sharply decreased.

\section{Miscellaneous}

The effects of incubating the particulate fraction with TPB prior to the addition of isotope is shown in Table 2. Preincubation does not significantly increase PhA labelling. Extended treatment with TPB, however, lowers PhIP and $\mathrm{PhIP}_{2}$ labelling. Other experiments were designed to study the effect of TPB on previously labelled lipids (Tables $3 \mathrm{a}$ and $3 \mathrm{~b}$ ) to observe possible degradative processes. Excess unlabelled ATP was added with TPB to lower its specific activity (Table 3a) or ATP was removed by reaction with deoxyglucose/ hexokinase (Table $3 \mathrm{~b}$ ). There are no significant effects of TPB on the degradation of these lipids except for a suggestive decrease in PhIP in the presence of TPB (Table 3b).

\section{Influence of atropine}

To investigate the possible correlation between AChand TPB-stimulated phospholipid labelling, we studied the effect of atropine on the increased $\mathrm{PhA}$ labelling (Table 4a). Atropine did not block the TPB stimulation. Since this was in contrast to previous findings by HOLLANDER et al. (1970) in goldfish brain, we repeated these experiments (Table $4 \mathrm{~b}$ ). Here also atropine was ineffective in blocking the TPB-stimulated labelling in all of five separate experiments. The effectiveness of the atropine used was tested by employing the same preparation in experiments with guinea pig synaptosomes in which it effectively blocked ACh stimulation of $\mathrm{PhA}$ and $\mathrm{PhI}$ labelling (SCHACHT \& AGRANOFF, 1973).

\section{Comparison with known detergents}

Since diglyceride kinase is known to be stimulated by certain detergents (HokIN \& HoKIN, 1959; LAPETINA \& HAWTHORNE, 1971), we compared the effect of TPB on phospholipid labelling with the effects of some detergents in the same system. Sodium DOC, although stimulating $\mathrm{PhA}$ labelling to a far greater extent (Fig. 2), exhibited a similar pattern to TPB, a very narrow concentration optimum for PhA labelling, lesser stimulation of PhIP and $\mathrm{PhIP}_{2}$ labelling and strong inhibition of labelling at higher concentrations. In addition, Table 5 shows that TPB in the presence of DOC does not produce any further stimulation (i.e. the two effects are not additive). SDS also showed a very similar effect on the incorporation of ${ }^{32} \mathrm{P}$ into the lipids (Fig. 3). To obtain an independent measure of detergency, we examined a dyedetergent interaction, with pinacyanol. Changes in

TABle 3. EFFeCt OF TPB on PREVIOUSLY Labelled lipids

Treatment at

\begin{tabular}{|c|c|c|c|c|}
\hline $10 \mathrm{~min}$ & $15 \mathrm{~min}$ & PhA & PhIP & $\mathrm{PhIP}_{2}$ \\
\hline & & \multicolumn{3}{|c|}{ d.p.m. ${ }^{32} \mathrm{P}$ incorporated } \\
\hline \multicolumn{5}{|c|}{ (a) Addition of unlabelled ATP $^{1}$} \\
\hline- & Incubation terminated & 1529 & 2117 & 128 \\
\hline$\ldots$ & $10 \mathrm{mM}$ ATP & 1436 & 1960 & 215 \\
\hline- & $10 \mathrm{~mm} \mathrm{ATP}+2 \times 10^{-4}$ м TPB & 1537 & 2028 & 205 \\
\hline \multicolumn{5}{|c|}{ (b) Addition of deoxyglucose and hexokinase ${ }^{2}$} \\
\hline Incubation terminated & - & 2016 & 3011 & 356 \\
\hline Deoxyglucose/hexokinase & Incubation terminated & 1826 & 3114 & 321 \\
\hline Deoxyglucose/hexokinase & None & 1647 & 2718 & 212 \\
\hline Deoxyglucose/hexokinase & $2 \times 10^{-4} \mathrm{M}$ TPB & 1530 & 2382 & 194 \\
\hline
\end{tabular}

\footnotetext{
${ }^{1}$ The particulate fraction ( $1 \mathrm{mg}$ protein) was incubated for $15 \mathrm{~min}$ with $3 \mu \mathrm{Ci}\left[{ }^{32} \mathrm{P}\right] \mathrm{ATP}$. At this point the incubation was terminated or the additions indicated were made and incubations continued for further 10 min as described in "Methods."

${ }^{2}$ The particulate fraction (1 mg protein) was incubated for $10 \mathrm{~min}$ with $4 \mu \mathrm{Ci}\left[{ }^{32} \mathrm{P}\right] \mathrm{ATP}$ as described in 'Methods'. At $10 \mathrm{~min}$ 2-deoxyglucose (35 mM) and hexokinase (Boehringer, Mannheim; $1 \mu \mathrm{l}$ ) were added when indicated; at $15 \mathrm{~min}$ further additions were made and remaining incubations were terminated 15 min thereafter.
} 
TABle 4. EFFect of atropine on TPB stimulation

\begin{tabular}{|c|c|c|c|c|c|c|}
\hline \multirow[b]{2}{*}{ Atropine } & \multicolumn{2}{|c|}{$\mathrm{PhA}$} & \multicolumn{2}{|c|}{ PhIP } & \multicolumn{2}{|c|}{$\mathrm{PhIP}_{2}$} \\
\hline & - TPB & $+\mathrm{TPB}$ & - ТPB & + TPB & $-\mathrm{TPB}$ & $+\mathrm{TPB}$ \\
\hline & \multirow{2}{*}{\multicolumn{6}{|c|}{ d.p.m. ${ }^{32} \mathrm{P}$ incorporated }} \\
\hline (a) Guinea pig corte ${ }^{1}$ & & & & & & \\
\hline 0 & 1960 & 7710 & 4480 & 5490 & 320 & 205 \\
\hline $10^{-5} \mathrm{M}$ & 2119 & 7610 & 4701 & 5470 & 317 & 190 \\
\hline $10^{-4} \mathrm{M}$ & 2190 & 7226 & 4532 & 5640 & 300 & 185 \\
\hline $\begin{array}{l}10^{-3} \mathrm{M} \\
\text { (b) Goldfish brain }{ }^{2}\end{array}$ & 1940 & 6730 & 4531 & 5890 & 300 & 210 \\
\hline 0 & 3860 & 14550 & 1465 & 1460 & 150 & 110 \\
\hline $10^{-4} \mathrm{M}$ & 3545 & 15080 & 1400 & 1435 & 175 & 130 \\
\hline $10^{-3} \mathrm{M}$ & 3975 & 14330 & 1505 & 1470 & 173 & 110 \\
\hline
\end{tabular}

${ }^{1}$ The particulate fraction ( $1 \mathrm{mg}$ protein) was incubated for $5 \mathrm{~min}$ with $3 \mu \mathrm{Ci}\left[{ }^{32} \mathrm{P}\right] \mathrm{ATP}$. Atropine when indicated was added $15 \mathrm{~min}$ and TPB $\left(2 \times 10^{-4} \mathrm{M}\right)$ was added 5 min prior to the addition of the isotope.

${ }^{2}$ Goldfish brain particulate fraction $\left(0.9 \mathrm{mg}\right.$ protein) was incubated for $10 \mathrm{~min}$ with $10 \mu \mathrm{Ci}\left[{ }^{32} \mathrm{P}\right] \mathrm{ATP}$ according to Hollander et al. (1970). Atropine was added $10 \mathrm{~min}$ and TPB $\left(5 \times 10^{-4} \mathrm{M}\right)$ was added 5 min prior to the addition of the $\left[{ }^{32} \mathrm{P}\right]$ ATP.

absorbance have been interpreted to reflect micelle formation (ZAHLER et al., 1968). An absorption minimum was obtained for both SDS and TPB in the $2-10 \mu \mathrm{g} / \mathrm{ml}$ range.

\section{DISCUSSION}

Increased labelling of phospholipids by ${ }^{32} \mathbf{P}_{j}$, in particular of $\mathrm{PhA}$ and phosphatidylinositol, in response to cholinergic agents has been well documented for brain tissue in vivo (SCHACHT \& AGRANOFF, 1972b; FRIEDEL \& SCHANBERG, 1972) as well as in vitro (Hokin \& HokIn, 1958; Yagihara \& HaWTHORNe, 1972; SCHACHT \& AGRANOFF, 1972a). Suggestions have been made that this phenomenon is related to ion transport (HoKIN et al., 1960), synaptic events (DURELL et al., 1969), or neurotransmitter uptake (SCHACHT, NeAle \& AGRAnoff, in press). Its precise nature, however, remains uncertain. Similarly, various explanations have been offered for the biochemical mechanism of the stimulated lipid labelling: stimulation of diglyceride kinase (HокIN, 1969); stimulation of phosphodiesteratic cleavage of phosphatidylinositol (Durell et al., 1968) or PhIP and PhIP 2 (Durell et al., 1969). Recently, a stimulation of PhA hydrolysis by ACh has been shown (SCHACHT \& AGRanofF, 1973).

These biochemical investigations were hampered by the fact that the effect of $\mathrm{ACh}$ or carbamylcholine on CNS phospholipids could be observed only in whole tissue (brain slices) or intact subcellular fragments such as nerve ending particles. Although nerve endings may lend themselves more readily to studies of biochemical mechanisms than whole tissue, they are resealed anucleate neuronal fragments undoubtedly capable of
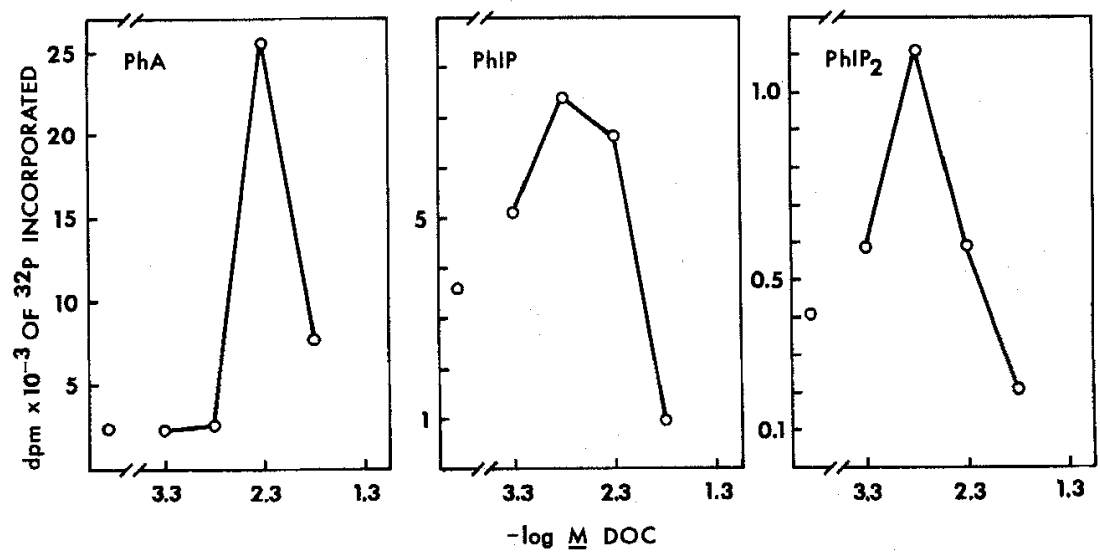

FIG. 2. The particulate fraction of guinea pig cerebral cortex (1 mg protein) was incubated for $5 \mathrm{~min}$ with $3 \mu \mathrm{Ci}\left[{ }^{32} \mathrm{P}\right]$ ATP as described in 'Methods'. 
TABLE 5. INFLuence OF TPB AND DOC ON LIPID LABELLING

\begin{tabular}{|c|c|c|c|c|c|c|}
\hline \multirow[b]{2}{*}{ Desoxycholate } & \multicolumn{2}{|c|}{$\mathrm{PhA}$} & \multicolumn{2}{|c|}{ PhIP } & \multicolumn{2}{|c|}{$\mathrm{PhIP}_{2}$} \\
\hline & - ТРB & + TPB & - TPB & $+\mathrm{TPB}$ & $-\mathrm{TPB}$ & + TPB \\
\hline \multicolumn{7}{|c|}{ d.p.m. ${ }^{32} \mathrm{P}$ incorporated } \\
\hline 0 & 2100 & 6400 & 3034 & 4100 & 353 & 325 \\
\hline $1.5 \times 10^{-3} \mathrm{M}$ & 2630 & 6100 & 5995 & 3225 & 968 & 390 \\
\hline $5 \times 10^{-3} \mathrm{M}$ & 15950 & 12310 & 5205 & 2122 & 105 & 65 \\
\hline
\end{tabular}

The particulate fraction ( $1 \mathrm{mg}$ protein) was incubated for $5 \mathrm{~min}$ with $3 \mu \mathrm{Ci}\left[{ }^{32} \mathrm{P}\right] \mathrm{ATP}$ as described in 'Methods'. TPB was $2 \times 10^{-4} \mathrm{M}$.

compartmentalization present in whole cells. The report, therefore that TPB could act as a parasympathomimetic drug (SEIFTER et al., 1968) and also stimulate phospholipid labelling in broken cell preparations of goldfish brain (HoLlANDER et al., 1969, 1970) gave promise that TPB might serve as a probe in the elucidation of the biochemistry of the ACh effect.

In the present studies with guinea pig cortex subcellular fractions, TPB stimulated labelling of PhA from $\gamma-\left[{ }^{32} \mathrm{P}\right]$ ATP approx. two- to three-fold in all subcellular fractions studied (Table 1). This contrasts with the effect of $\mathrm{ACh}$ on lipid labelling which we had shown to be specific for a 'light' and therefore presumably cholinergic nerve ending fraction (SCHACHT \& AGranoff, 1972a). Labelling of PhIP and $\mathrm{PhIP}_{2}$ was hardly affected at this concentration of TPB. The dose-response curve for TPB showed a sharp optimum for stimulated labelling around $10^{-4} \mathrm{M}$ and a decrease in labelling of the polyphosphoinositides occurred at concentrations which were no longer stimulatory for $\mathrm{PhA}$ labelling. Thus, hydrolysis of $\mathrm{PhIP}$ and/or $\mathrm{PhIP}_{2}$ does not appear to be directly linked to the stimulation of PhA labelling (HOLLANDER et al., 1970). In other experiments with cholinergic agents the increase in $\mathrm{PhA}$ labelling and decrease in PhIP and $\mathrm{PhIP}_{2}$ labelling have been dissociated on a number of grounds (Schacht \& AgranofF, 1974). Further evidence against the possibility that formation of diglyceride via degradation of $\mathrm{PhIP}$ and/or $\mathrm{PhIP}_{2}$ is responsible for increased $\mathrm{PhA}$ labelling by TPB comes from present experiments in which preparations were incubated with TPB prior to labelling (Table 2) or labelled prior to the addition of TPB (Table 3 ). Although pre-incubation with TPB lowers PhIP levels at longer times, it is not accompanied by labelling of $\mathrm{PhA}$ exceeding that achieved by adding tetraphenylborate at 0 time; there is, therefore, no evidence for the formation of an intermediate during the preincubation period, nor is the decrease in PhIP (Tables 2 and 3) of the order of magnitude that would suggest that this lipid serves as a diglyceride donor.

A block by atropine of the TPB effect, the strongest evidence for a possible cholinergic action of TPB on phospholipid labelling (HoLLANDER et al., 1970), was not evident in incubations with guinea pig cortex fractions (Table 4). We therefore reinvestigated the TPB and atropine actions on goldfish brain particulate fractions (Table 4b). Here also, no block of TPBstimulated labelling by atropine was observed.

The strikingly sharp concentration optimum for TPB-stimulated labelling of $\mathrm{PhA}$ in goldfish brain (Hollander et al., 1970) as well as in our studies (Fig. 1) suggested comparison to the stimulation of diglyceride kinase by DOC where a similar observation
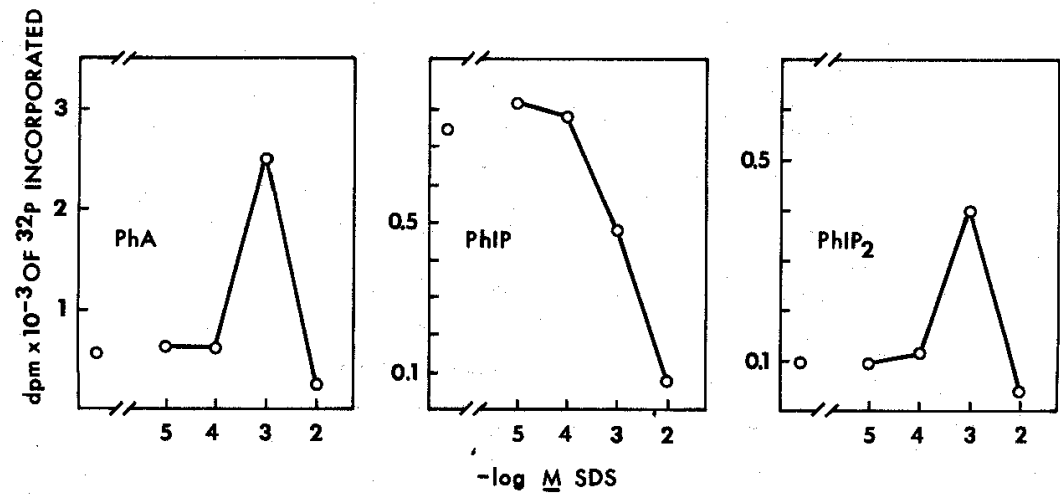

FIG. 3. The particulate fraction of guinea pig cerebral cortex (1 $\mathrm{mg}$ protein) was incubated for $5 \mathrm{~min}$ with $3 \mu \mathrm{Ci}\left[{ }^{32} \mathrm{P}\right] \mathrm{ATP}$ as described in 'Methods'. 
had been made (HoKIn \& HoKIN, 1959; LAPETINA \& HAWTHORNE, 1971). We found indeed that the shapes of the dose-response curves for TPB, DOC and SDS were similar, indicating a related action of TPB and the detergents on the labelling. Furthermore, the additional presence of TPB in incubations with DOC which is known to stimulate diglyceride kinase, did not produce an additional increase in labelling, again indicating that TPB action was not different from that of DOC.

TPB, although generally not looked upon as a detergent, has an anionic charge and hydrophobic phenyl groups, structural characteristics of amphiphatic molecules. The cell-dispersing properties of TPB which surpass those of other potassium-chelating agents (RAPPAPORT \& Howze, 1966b) may indeed be aided by such weak detergent action in addition to its potassium-chelating properties. This idea is strengthened by the finding that TPB-dispersed cells are unable to carry on normal ribosomal protein synthesis (FrIEDMAN \& EPSTEIN, 1967), and that TPB changes the permeability of the chloroplast membrane (HORTON \& PACKER, 1968). Other properties of TPB which cannot be explained by its potassium-chelating capacity such as the inhibition of various enzymes (STANBURY \& WiCKEN, 1969) or the uncoupling of oxidative phosphorylation (UTSUMI \& PACKER, 1967) should be reconsidered from the standpoint of detergent action. In any case, the stimulation of phospholipid labelling in brain by TPB appears to be due primarily to a detergent-like activation of diglyceride kinase and not due to the potassium-chelating or parasympathomimetic properties of this drug.

Acknowledgement-The authors wish to acknowledge the excellent technical assistance of Mrs. MARIANNE ANDrEws.

\section{REFERENCES}

Durell J., Garland J. T. \& Friedel R. O. (1969) Science $165,862-866$.

Durell J., Sodd M. A. \& Friedel R. O. (1968) Life Sci. (II) 7, 363-368.

Friedel R. O. \& Schanberg S. M. (1972) J. Pharmacol. exp. Ther. 183, 326-332.

Friedman T. \& EPSTEIN C. J. (1967) Biochim biophys. Acta $138,622-624$.
GlynN I. M. \& ChAPPEL J. B. (1964) Biochem. J. 90, $147-154$.

Hajra A. K., Seguin E. B. \& Agranoff B. W. (1968) J. biol. Chem. 243, 1609-1616.

Harris C. C. \& Leone C. A. (1966) J. Cell Biol. 28, 405-408.

Herz F., Kaplan E. \& Luna I. G. (1971) Experientia 27, $1260-1261$.

HoKIN L. E. (1969) In Structure and Function of Nervous Tissue (Bourne G. H., ed.) Vol. 3, pp. 161-184. Academic Press, New York.

Hokin L. E. \& Hokin M. R. (1958) J. biol. Chem. 233, $822-826$.

Hokin M. R. \& Hokin L. E. (1959) J. biol. Chem. 234, 1381-1386.

Hokin M. R., HoKin L. E. \& Shelp W. D. (1960) J. gen. Physiol. 44, 217-226.

Hollander J., Hallenbeck J. M. \& Agranoff B. W. (1969) Biochem. biophys. Res. Comm. 35, 346-353.

Hollander J., Hallenbeck J. M. \& AgranofF B. W. (1970) J. Neurochem. 17, 1247-1261.

Horton A. A. \& PACKer L. (1968) Arch. Biochem. Biophys. 128, 820-823.

Lapetina E. G. \& Hawthorne J. N. (1971) Biochem. $J$. 122, 171-179.

Lowry O. H., Rosebrough N. J., FARR A. L. \& Randall R. J. (1951) J. biol. Chem. 193, 265-275.

Rappaport C. \& Howze G. B. (1966a) Proc. Soc. exp. Biol. Med. 121, 1010-1016.

Rappaport C. \& Howze G. B. (1966b) Proc. Soc. exp. Biol. Med. 121, 1016-1021.

SChaChT J. \& Agranoff B. W. (1972a) J. biol. Chem. 247, 771-777.

Schacht J. \& Agranoff B. W. (1972b) J. Neurochem. 19, - 1417-1421.

SCHACHT J. \& Agranoff B. W. (1973) Biochem. biophys. Res. Comm. 50, 934-941.

Schacht J. \& AGranoff B. W. (1974) In Neurochemistry of Cholinergic Receptors (DE RoBertis E. \& Schacht J. eds.). Raven Press, New York.

Schacht J., Neale E. A. \& Agranoff B. W. (1974) $J$. Neurochem. in press.

Seifter J., Guideri G. \& Seifter E. (1968) Eur. J. Pharmacol. 3, 263.

Stanbury J. B. \& WiCken J. V. (1969) Biochim. biophys. Acta 178, 403-405.

Utsumi K. \& PaCker L. (1967) Arch. Biochem. Biophys. 122, 509-515.

Wittig G., Keicher S., Rückert A. \& RafF P. (1949) Annalen 563, 110-126.

Yagihara Y. \& Hawthorne J. N. (1972) J. Neurochem. 19, 355-367.

Zahler W. L., Barden R. E. \& Cleland W. W. (1968) Biochim. biophys. Acta 164, 1-11. 